\title{
DAMPAK KUALITAS INSTITUSI TERHADAP PEREKONOMIAN INDONESIA
}

\section{THE IMPACT OF INSTITUTIONAL QUALITY ON INDONESIA'S ECONOMY}

\author{
Aulia Keiko Hubbansyah ${ }^{1)}$, Eka Sudarmaji ${ }^{2)}$, Shinta Budi Astuti ${ }^{3)}$ \\ 1) Universitas Pancasila; ${ }^{2)}$ Universitas Pancasila; ${ }^{3)}$ Universitas Pancasila \\ Correspondence author: akhubbansyah@univpancasila.ac.id
}

\begin{abstract}
This study aims to analyze the impact of institutional quality on the Indonesian economy proxied by various macroeconomic variables. By using quarterly data for the 1996q1 - 2017q2 period and the system equation approach, this study finds that institutions, which are represented by the variables ROL, VOAC, GEF and REGQUA, have a major impact on economic dynamics through the investment mechanism. The simulation results of the research model show that improving institutional conditions can improve Indonesia's economic fundamentals.
\end{abstract}

Keywords: Institution, Development, Economy

\begin{abstract}
ABSTRAK
Studi ini bertujuan untuk menganalisis dampak kualitas institusi terhadap perekonomian Indonesia yang ditinjau dari berbagai ukuran variabel makroekonomi. Dengan menggunakan data kuartalan periode 1996q1 - 2017q2 dan pendekatan persamaan sistem, penelitian ini menemukan bahwa kelembagaan, yang di-proxy-kan oleh variabel ROL, VOAC, GEF dan REGQUA, memiliki dampak yang besar terhadap dinamika perekonomian melalui jalur transmisi investasi. Hasil simulasi model penelitian memperlihatkan bahwa perbaikan kondisi kelembagaan dapat memperbaiki fundamental ekonomi Indonesia.
\end{abstract}

Keywords: Kelembagaan, Pembangunan, Perekonomian.

\section{PENDAHULUAN}

Pembangunan ekonomi menjadi salah satu isu utama yang dibahas secara ekstensif dalam literatur ekonomi. Isu mengenai pembangunan ekonomi ini penting karena berkaitan dengan upaya meningkatkan kesejahteraan masyarakat. Secara historis, tidak ada satu pun negara di dunia yang mampu mentransformasi dirinya dari negara miskin menjadi negara maju tanpa didukung oleh pembangunan ekonomi yang baik.

Tidak bisa dipungkiri bahwa peran institusi — dalam kaitannya dengan kinerja perekonomian - menjadi salah satu isu yang memicu banyak perdebatan dalam kajian-kajian ekonomi. Studi empiris cross country, yang dikombinasikan dengan studi pada level mikro, memperlihatkan bukti yang kuat mengenai pentingnya peran institusi dalam menentukan tingkat kemajuan ekonomi negara-negara di dunia (Hall dan Jones, 1999; Acemoglu, Johnson dan Robinson, 2001).

Negara-negara dengan kualitas institusi yang kuat -ditandai dengan adanya penegakan hukum yang efektif, iklim bisnis yang kondusif, perlindungan atas hak kepemilikan, dan marketfriendly - memiliki posisi yang lebih baik dalam menarik investasi, berpartisipasi dalam perdagangan dan mampu memanfaatkan sumberdaya fisik dan manusia secara lebih efesien. Hasilnya, pertumbuhan ekonomi mereka dapat tumbuh tinggi dan juga berkelanjutan (Wanjuu dan Roux, 2017). Perlindungan 
hak kepemilikan, penegakan hukum yang efektif dan birokrasi yang efesien, bersama dengan norma serta tata aturan (civic mores), diketahui sebagai faktor determinan penting yang mempunyai hubungan kuat dengan kinerja perekonomian (Ferrini, 2012).

Penekanan pada pentingnya peran faktor non-ekonomi, atau institusi, dalam menentukan baik-buruknya kinerja perekonomian ini sangat berbeda dengan teori-teori pertumbuhan ekonomi klasik, seperti Solow (1956), yang menekankan pada akumulasi kapital fisik dan teknologi sebagai sumber pertumbuhan. Sementara itu, teori pertumbuhan endogenous yang dikembangkan Romer dan Lucas -yang juga masih bagian dari kelompok neoklasik - menekankan pentingnya peran human capital dan kapasitas inovasi terhadap perkembangan ekonomi (Petrakos, et.al, 2008).

Di Indonesia, studi yang membahas kinerja perekonomian dari perspektif kelembagaan ekonomi masih jarang dilakukan. Kalaupun ada, cakupan analisis dari studi-studi tersebut relatif terbatas pada aspek tertentu saja, seperti pertumbuhan ekonomi dan kemiskinan (Junaidi dan Patra 2017; Hapsari, 2018). Oleh karena itu, kedalaman analisis yang ditawarkan, terutama yang terkait dengan peranan institusi (kelembagaan) dalam mendinamisasi perekonomian, masih belum diketahui secara optimal.

Terkait hal di atas, penelitian ini bertujuan menjembatani gap literatur dalam kajian ekonomi pembangunan di Indonesia dengan menganalisis peran kelembagaan terhadap kinerja perekonomian secara lebih komprehensif. Studi ini tidak hanya melibatkan pertumbuhan ekonomi dan kemiskinan, sebagai proxy atau ukuran kinerja perekonomian, seperti Junaidi dan Patra (2017) dan Hapsari (2018), tetapi juga memasukkan berbagai variabel ekonomi lain, seperti penyerapan tenaga kerja, kinerja perdagangan, investasi, inflasi, dan sebagainya, yang belum dipertimbangkan di dalam penelitian sebelumnya. Karena melibatkan varibel pengamatan yang lebih besar, maka studi ini memiliki kelebihan, utamanya dalam menjelaskan mekanisme transmisi dari peran institusi terhadap perekonomian secara keseluruhan.

Dalam operasionalnya, studi ini mengadaptasi pendekatan persamaan sistem. Kelebihan utama dari persamaan sistem -yang sesuai dengan kebutuhan penelitian ini- adalah kemampuannya dalam mengakomodasi kompleksitas fenomena ekonomi ke dalam model. Diharapkan dengan mengadaptasi pendekatan sistem, akan diperoleh suatu pemahaman yang lebih menyeluruh atas suatu permasalahan.

\section{MATERI DAN METODE}

\section{Spesifikasi Model Empiris}

Institusi yang paling penting, secara empirik, adalah peran pemerintah dalam mengalokasikan dan menggunakan kekuasaan politik dan birokrasi yang dimilikinya. Makin efektif alokasi dan penggunaannya, maka makin besar pula kontribusinya dalam menghasilkan kualitas institusi yang memadai.

$G E F_{t}=a_{0}+a_{1} R O L_{t}+a_{2} V O A C_{t}+U \ldots$ (1)

Dimana $G E F_{t}$ adalah government effectiveness, yang menjadi proxy dari sejauhmana pemerintah mampu memanfaatkan kekuasan politik yang dimiliki untuk menghasilkan pelayanan publik yang berkualitas. Dalam konteks penelitian ini, $G E F_{t}$ diposisikan sebagai fungsi dari penegakan hukum (rule of law-ROL) dan akuntabilitas (VOAC). Makin kuat supremasi hukum di suatu negara, yang merupakan jiwa dari negara hukum, membuat kecenderungan pemerintahan berlangsung efektif akan lebih besar. Hal yang sama juga berlaku untuk akuntabilitas. Semakin kuat praktek dan dorongan akuntabilitas yang terdapat 
pada sebuah negara, maka efektivitas pemerintahan juga akan semakin tinggi.

$R E G Q U A_{t}=b_{0}+b_{1} G E F_{t}+U \ldots \ldots$ (2)

Kualitas institusi juga sangat terkait dengan kualitas regulasi yang dibuat oleh pemerintah $\left(R E G Q U A_{t}\right)$. Regulasi yang memiliki tingkat kepastian hukum yang memadai akan dapat menciptakan kondisi institusional yang juga kondusif. Pada prakteknya, hal ini sangat bergantung pada efektivitas pemerintah $\left(G E F_{t}\right)$ dalam memformulasi dan menentukan kebijakan publik yang baik. Dalam hal ini, makin efektif suatu pemerintahan, maka kualitas regulasi yang dihasilkan juga akan semakin tinggi.

Permintaan terhadap output suatu negara dengan ekonomi terbuka berasal dari konsumsi (C), investasi (I), belanja pemerintah $(\mathrm{G})$, ekspor (X) dan impor $(\mathrm{M})$. Teori konsumsi Keynes menjelaskan konsumsi dipengaruhi terutama oleh disposable income atau pendapatan disposable (Mankiw, 2003; Prasmuko dan Anugrah, 2010). Pendapatan disposable merupakan pendapatan dikurangi pajak, $Y_{d}$ $=Y-T$, di mana pajak merupakan faktor eksogen atau faktor yang sudah ditentukan. Persamaan pendapatan disposable mengikuti persamaan identitas sebagai berikut:

$Y d=Y-T$

Dimana $Y d$ adalah pendapatan disposable, $Y$ adalah output nasional dan $T$ adalah tax ratio yang diposisikan dalam studi ini sebagai variabel eksogen.

Lebih lanjut, konsumsi juga dipengaruhi oleh tingkat suku bunga (i). Suku bunga yang tinggi mengindikasikan besarnya opportunity cost. Tingginya tingkat suku bunga umumnya akan disikapi dengan penundaan konsumsi ke masa depan. Sebaliknya, dalam kondisi suku bunga rendah, konsumen lebih cenderung berbelanja daripada menabung. Spesifikasi model empiris yang diadaptasi dalam studi ini untuk konsumsi adalah

$$
C_{t}=c_{0}+c_{1} Y d_{t}+c_{2} D r_{t}+U \quad \ldots \ldots \text { (4) }
$$

Dimana $d r_{t}$ adalah suku bunga deposito riil dan $c_{0}$ menunjukkan autonomous consumption yang tidak terpengaruh oleh tingkat pendapatan.

Komponen agregat kedua dari total output adalah investasi. Secara teoretik, investasi sangat bergantung pada biaya modal (cost of capital). Makin tinggi biaya modalnya - yang dicerminkan dari tingkat suku bunga pinjaman, maka pelaku usaha akan cenderung mengurangi permintaan kreditnya. Selain suku bunga pinjaman, beberapa studi, seperti Stirroh (2003), Yuliadi (2008), dan Prasmuko et al. (2010) menyatakan bahwa output mempengaruhi investasi. Dalam studi ini, kualitas institusi yang di-proxy-kan oleh REGQUA, yang menurut Myrdal dan Acemoglu merupakan salah satu sumber pembangunan ekonomi yang penting, mempengaruhi jalannya perekonomian melalui jalur investasi. Kualitas institusi, dalam kenyataannya, berkaitan dengan ekspetasi pelaku usaha atas adanya kepastian hukum dan aturan yang tidak berbelit yang membuat ekonomi berbiaya tinggi. Institusi yang ekstraktif (kualitas rendah) mengindikasikan tingginya risiko investasi di suatu negara sehingga memberi sinyal negatif terhadap investasi. Spesifikasi model empiris untuk pengujian investasi adalah sebagai berikut:

$I_{t}=d_{0}+d_{1} L r+d_{1} R E G Q U A_{t}+d_{2} Y d_{t}+$ $d_{3} E R_{t}+U \ldots \ldots$ (5)

Di mana $I_{t}=$ investasi, $L r_{t}=$ suku bunga pinjaman, $R E G Q U A_{t}=$ kualitas regulasi, $Y_{d}$ = disposable income, dan $E R_{t}=$ nilai tukar.

Komponen agregat ketiga dalam permintaan output adalah belanja pemerintah yang disimbolkan dengan $G$. Berbeda dengan komponen lain, belanja pemerintah merupakan faktor eksogen -nilainya tidak ditentukan di dalam sistem. Konsumsi pemerintah merupakan alat yang 
sangat penting dalam mempengaruhi output, inflasi, dan pengangguran dalam jangka pendek karena memiliki efek multiplier yang lebih besar daripada konsumsi rumah tangga. Konsumsi pemerintah sangat tergantung dari jumlah pendapatan yang diperoleh dari pajak serta pembiayaan. Dalam penelitian ini, pengeluaran pemerintah ditempatkan sebagai variabel eksogen dengan pertimbangan bahwa variabel tersebut sangat bergantung pada keputusan pemerintah dan tidak ditentukan dalam sistem (Anugrah 2010).

Perekonomian terbuka (open economy) dicirikan dengan adanya perdagangan antarnegara. Karena itu, faktor ekspor dan impor akan turut mempengaruhi output perekonomian negara tersebut. Ekspor berarti pengiriman atau penjualan barang dari dalam negeri ke luar negeri. Nilai ekspor akan ditentukan oleh tingkat perekonomian negara tujuan. Faktor output luar negeri akan berpengaruh positif dimana peningkatan output luar negeri akan meningkatkan permintaan ekspor dalam negeri.

Faktor nilai tukar juga memiliki peran dalam mempengaruhi permintaan ekspor. Depresiasi nilai tukar dalam negeri akan membuat harga produk dalam negeri menjadi murah, sehingga daya saing produk dalam negeri akan meningkat. Sehingga, penurunan nilai tukar akan diikuti dengan peningkatan ekspor dan berdampak juga pada peningkatan output (Hallwood et al. 2000). Selain itu, faktor output negara lain juga mempengaruhi ekspor. Output AS dan China, sebagai dua negara dengan ukuran ekonomi terbesar di dunia, digunakan sebagai proxy permintaan ekspor dari pasar dunia atas produk Indonesia. Kedua negara ini juga termasuk negara-negara yang menjadi tujuan utama ekspor Indonesia. Sehingga, pertambahan atau penurunan output pada kedua negara akan memberi dampak terhadap kinerja ekspor Indonesia.
Berkaitan dengan peran komoditas non-fuel, pergerakan indeks harga global komoditas non-fuel, yang menjadi andalan sektor ekspor Indonesia, menjadi sangat penting untuk diperhitungkan. Terutama untuk kasus Indonesia yang merupakan negara pengekspor, di mana porsi ekspor komoditas non-fuel mencapai 80 persen dari total ekspor. Spesifikasi empiris persamaan ekspor adalah sebagai berikut:

$X_{t}=e_{0}+e_{1} E R_{t}+e_{2} Y c h_{t}+e_{3} Y u s_{t}+$ esnonfuel $_{t}+e_{5} I_{t}+U$..... (6)

Dimana $X_{t}=$ ekspor, $E R_{t}=$ nilai tukar $(\mathrm{Rp} / \mathrm{USD}), Y_{c h} h_{t}=$ output China, $Y u s_{t}=$ output Amerika Serikat, nonfuel $_{t}=$ indeks harga global komoditas non-fuel dan $I_{t}=$ investasi.

Sedangkan impor lebih dipengaruhi oleh perekonomian dalam negeri, dimana pendapatan mencerminkan daya beli masyarakat. Nilai impor juga dipengaruhi oleh pergerakan nilai tukar. Apresiasi nilai tukar akan diikuti oleh naiknya permintaan impor, terutama untuk impor barang konsumsi. Hal tersebut disebabkan apresiasi nilai tukar mengakibatkan harga barang impor jadi lebih murah, sehingga permintaan akan barang tersebut akan meningkat. Persamaan impor dapat dijabarkan sebagai berikut (Anugrah, 2010):

$M_{t}=f_{0}+f_{1} Y d_{t}+f_{2} \operatorname{Infus}_{t}+f_{3} E R_{t-1}+U$

Dimana $M_{t}=$ impor, $Y d_{t}=$ nilai tukar $(\mathrm{Rp} / \mathrm{USD})$, Infus $_{t}=$ inflasi AS dan $E R_{t-1}=$ lag nilai tukar. Secara agregat, dalam perekomian terbuka output perekonomian dari sisi permintaan mengikuti persamaan identitas sebagai berikut:

$$
Y_{t}=C_{t}+I_{t}+G_{t}+X_{t}-M_{t} \ldots \ldots \text { (8) }
$$

Studi ini juga mengamati bagaimana dampak pertumbuhan output nasional terhadap kesempatan kerja. Perbaikan kualitas institusi, yang diharapkan mampu 
meningkatkan aliran investasi dan mendorong pembangunan ekonomi, pada akhirnya harus mampu menciptakan kesempatan kerja dalam jumlah yang memadai. Apalagi kondisi angkatan kerja Indonesia terus bertumbuh setiap tahunnya. Secara teknis, spesifikasi persamaan kesempatan kerja adalah sebagai berikut:

Pekerja $_{t}=h_{0}+h_{1} I_{t}+U \ldots \ldots$ (9)

Dimana pekerja $_{t}=$ kesempatan kerja, dan $I_{t}$ = Investasi.

Selain kesempatan kerja, outcome lain yang dianalisis dalam studi ini dari kenaikan output nasional adalah bagaimana dampaknya terhadap kemiskinan. Dalam hal ini, kenaikan output nasional mempengaruhi kemiskinan melalui kesempatan kerja. Makin besar kesempatan kerja, maka tingkat kemiskinan akan semakin rendah. Persamaan kemiskinan dalam penelitian ini dibagi menjadi dua, yakni kemiskinan kota dan kemiskinan desa.

Miskot $_{t}=i_{0}+i_{1}$ Pekerja $_{t}+i_{2}$ Inf $_{t}+U \ldots(10)$

Misdes $_{t}=j_{0}+j_{1}$ Pekerja $_{t}+j_{2} \operatorname{Inf}_{t}+U \ldots$ (11)

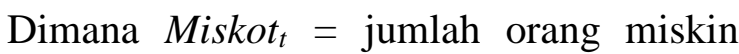
kota, Misdes $_{t}=$ jumlah orang miskin desa, Pekerja $_{t}=$ kesempatan kerja dan $I n f_{t}=$ inflasi.

Selain kesempatan kerja, kemiskinan juga sangat ditentukan kondisi inflasi. Dalam hal ini, ketika terjadi kenaikan harga secara umum, yang disebut inflasi, maka jumlah orang miskin akan cenderung meningkat. Ini karena, kenaikan harga berefek terhadap turunnya daya beli masyarakat, yang pada gilirannya menyebabkan tingkat kemiskinan meningkat.

$K_{E M I S}=M_{t} I S K O T_{t}+M I S D E S_{t}$

Secara akumulatif, total kemiskinan di Indonesia $\left(K E M I S_{t}\right)$ merupakan hasil penjumlahan dari kemiskinan yang ada di kota $\left(\right.$ Miskot $\left._{t}\right)$ maupun di desa $\left(\right.$ Misdes $\left._{t}\right)$.

\section{Model dan Teknik Estimasi}

Penelitian ini menggunakan pendekatan ekonometrik simultaneous equations atau persamaan simultan. Pendekatan ini memiliki kelebihan dalam menangkap kompleksitas hubungan antarvariabel yang dianalisis dalam model (Gujarati, 2003). Sistem persamaan simultan merupakan himpunan persamaan di mana variabel endogen dalam satu atau lebih persamaan juga merupakan variabel eksogen dalam beberapa persamaan lainnya. Oleh karena itu, variabel dalam model simultan dapat berperan ganda, baik sebagai variabel eksogen maupun endogen.

Identifikasi struktur model merupakan langkah awal dalam menyusun model simultan yang menentukan apakah estimasi parameter dapat diselesaikan atau tidak. Proses identifikasi dapat menggunakan dua metode yaitu, order condition dan rank condition (Enders, 2004), di mana prosedur order condition saja tidak cukup dan perlu ditambahkan prosedur rank condition sebagai syarat kecukupan (sufficient). Dalam hal ini agar sebuah sistem persamaan simultan dengan M persamaan struktural dapat diidentifikasi, maka persamaan tersebut harus memiliki M-1 variabel endogen.

Untuk sejumlah $\mathrm{m}$ variabel endogen di dalam model, $\mathrm{K}$ total variabel yang ditetapkan terlebih dahulu (predetermined) di dalam model, dan $\mathrm{k}$ jumlah variabel predetermined dalam persamaan yang diestimasi, maka order condition mengikuti ketentuan berikut:

a) Jika $(\mathrm{K}-\mathrm{k})=(\mathrm{m}-1)$ maka persamaan tersebut dikatakan exactly identified.

b) Jika (K-k) > (m-1) maka persamaan tersebut over identified

c) Jika $(\mathrm{K}-\mathrm{k})<(\mathrm{m}-1)$ maka persamaan tersebut under identified 
Suatu persamaan dapat diestimasi apabila persamaan tersebut kondisinya exactly atau over identified. Terkait dengan estimasi model, terdapat tiga teknik yang bisa digunakan. Pertama, indirect least square, teknik ini hanya bisa digunakan untuk persamaan struktural yang exactly identified. Kedua, ordinary least square, teknik ini diterapkan pada persamaan struktural yang overidentified, akan tetapi tidak terdapat kendala endogenitas. Ketiga, two stage least square (TSLS), teknik ini dipakai untuk meng-estimasi persamaan struktural yang overidentified dan memiliki persoalan endogenitas.

Pemilihan teknik estimasi yang tepat didasarkan atas dua hal, yakni (i) identifikasi perbandingan jumlah variabel endogen dan eksogen, dan (ii) permasalahan atau kendala endogenitas yang terdapat dalam persamaan strukturalnya. Dalam konteks penelitian ini, hasil identifikasi terhadap model penelitian menunjukkan bahwa teknik estimasi two stage least square dapat diterapkan.

\section{Validasi Model Penelitian}

Untuk mengetahui apakah model cukup valid untuk membuat suatu simulasi alternatif kebijakan, maka perlu dilakukan suatu validasi model dengan tujuan untuk menganalisis sejauh mana model tersebut dapat mewakili dunia nyata (Pindyck and Rubinfield 1998). Adapun kriteria statistik untuk memvalidasi nilai pendugaan model ekonometrika yang digunakan adalah Theil's Inequality Coefficient $(U)$.

$U$ adalah perbandingan RMSE dengan penjumlahan rata-rata kuadrat nilai estimasi dan rata-rata kuadrat nilai observasi suatu model atau variabel. Nilai U maksimum adalah satu (estimasi model atau variabel naif) dan nilai $U$ minimum nol (estimasi model atau variabel sempurna). Jika nilai $U$ mendekati nol maka estimasi model atau variabel tersebut semakin valid.Nilai koefisien Theil (U) berkisar antara 1 dan 0 . Jika $U=0$ maka pendugaan model sempurna, jika $\mathrm{U}=1$ maka pendugaan model naif. Pada dasarnya makin kecil nilai UTheil's, maka pendugaan model pun semakin baik. Rumus statistik $U$ adalah sebagai berikut:

$$
U=\frac{\left[\frac{1}{n} \sum_{i=1}^{n}\left(A_{i}-P_{i}\right)^{2}\right]^{1 / 2}}{\left[\frac{1}{n} \sum_{i=1}^{n} A_{i}^{2}\right]^{1 / 2}+\left[\frac{1}{n} \sum_{i=1}^{n} P_{i}^{2}\right]^{1 / 2}}
$$

Nilai $U$ terdiri dari tiga komponen, yaitu proporsi bias (UM), proporsi varians (US) dan proporsi kovarians (UC). UM adalah perbandingan selisih nilai rata-rata estimasi dan nilai rata-rata observasi kuadrat dari suatu model. US merupakan perbandingan antara kuadrat selisih standar deviasi nilai estimasi dan standar deviasi nilai observasi suatu model. Sedangkan UC adalah ukuran unsystematic error dari estimasi suatu model atau variabel.

\section{Skenario Simulasi}

Simulasi pada dasarnya merupakan solusi matematis (mathematical solution) dari suatu kumpulan berbagai persamaan. Simulasi model dilakukan dengan berbagai alasan, misalnya untuk pengujian dan evaluasi model, analisis kebijakan historis dan untuk peramalan (Pindyck and Rubinfeld, 1998).

Dalam penelitian ini, simulasi model terutama ditujukan untuk menganalisis kebijakan historis yang dapat digunakan sebagai dasar peramalan di masa yang akan datang. Dalam studi ini, analisis kebijakan difokuskan pada dampak pembangunan aspek institusi terhadap perekonomian Indonesia. Simulasi kebijakan yang dilakukan meliputi, pertama, kenaikan indeks rule of law sebesar 100 basis poin. Kedua, kenaikan indeks voice and accountability sebesar 100 basis poin. Ketiga, kombinasi kenaikan indeks rule of law dan voice and accountability masingmasing sebesar 100 basis poin.

\section{Data dan Sumber Data}

Data yang digunakan dalam penelitian ini, antara lain meliputi, data 
output China dan Amerika Serikat, output Indonesia, indeks harga global komoditas non-fuel, deposit rate, Inflasi Indonesia, Inflasi US, nilai tukar rupiah terhadap dollar, tax ratio, ekspor, impor, dan investasi Indonesia, belanja pemerintah, indeks harga komoditas non-fuel, jumlah pekerja dan kemiskinan di Indonesia.

Sementara itu, untuk variabel kualitas institusi, studi ini menggunakan data rule of law, voice and accountability, regulatory quality dan government index, yang dilaporkan oleh Bank Dunia sebagai komponen pembentuk variabel institusi. Periode data yang digunakan adalah 1996 2017 dengan frekuensi kuarteran. Keterangan lengkap dari data yang digunakan dalam penelitian ini dapat dilihat pada tabel 1 berikut:

Tabel 1. Data dan Sumber Data

\begin{tabular}{|c|c|c|c|c|}
\hline No & Variabel & Nama Variabel & Tahun & Sumber \\
\hline 1 & Output China & Ych & 1996q1-2017q2 & IMF-IFS \\
\hline 2 & Output AS & Yus & $1996 q 1-2017 q 2$ & IMF-IFS \\
\hline 3 & Output Indonesia & $Y$ & $1996 q 1-2017 q 2$ & IMF-IFS \\
\hline 4 & Pendapatan Disposabel & $Y d$ & $1996 q 1-2017 q 2$ & IMF-IFS \\
\hline 4 & $\begin{array}{l}\text { Indeks Harga Komoditas Non- } \\
\text { Fuel }\end{array}$ & nonfuel & $1996 q 1-2017 q 2$ & IMF-IFS \\
\hline 5 & Real Deposite Rate & $D r$ & $1996 q 1-2017 q 2$ & IMF-IFS \\
\hline 6 & Real Lending Rate & $L r$ & $1996 q 1-2017 q 2$ & IMF-IFS \\
\hline 7 & Inflasi Indonesia & $\operatorname{Inf}$ & $1996 q 1-2017 q 2$ & IMF-IFS \\
\hline 8 & Inflasi Amerika Serikat & Infus & $1996 q 1-2017 q 2$ & IMF-IFS \\
\hline 9 & Nilai Tukar Rp/US & $E R$ & $1996 q 1-2017 q 2$ & IMF-IFS \\
\hline 10 & Rasio Pajak & $T$ & $1996 q 1-2017 q 2$ & IMF-IFS \\
\hline 11 & Ekspor & $X$ & $1996 q 1-2017 q 2$ & IMF-IFS \\
\hline 12 & Impor & $M$ & $1996 q 1-2017 q 2$ & IMF-IFS \\
\hline 13 & Investasi & $I$ & $1996 q 1-2017 q 2$ & IMF-IFS \\
\hline 14 & Belanja Pemerintah & $G$ & $1996 q 1-2017 q 2$ & IMF-IFS \\
\hline 15 & Kemiskinan & Kemis & $1996 q 1-2017 q 2$ & World Bank \\
\hline 16 & Kemiskinan Kota & Miskot & $1996 q 1-2017 q 2$ & World Bank \\
\hline 17 & Kemiskinan Desa & Misdes & $1996 q 1-2017 q 2$ & World Bank \\
\hline 18 & Pekerja & Pekerja & 1996q1-2017q2 & World Bank \\
\hline 19 & Rule of Law & RoL & $1996 q 1-2017 q 2$ & World Bank \\
\hline 20 & Voice and Accountability & Voac & $1996 q 1-2017 q 2$ & World Bank \\
\hline 21 & Regulatory quality & Regqua & $1996 q 1-2017 q 2$ & World Bank \\
\hline 22 & Government Effectiveness & $G E F$ & $1996 q 1-2017 q 2$ & World Bank \\
\hline
\end{tabular}

\section{HASIL DAN PEMBAHASAN}

Hasil estimasi persamaan government effectiveness (GEF) memperlihatkan pengaruh positif rule of law (ROL) dan voice and accountability (VOAC) terhadap
$G E F$. Ini menandakan bahwa makin baik kualitas penegakan hukum dan perlindungan terhadap hak berekspresi, maka akan semakin efektif kinerja pemerintahan dalam menyelenggarakan pelayanan publik.

Tabel 2. Hasil Estimasi Persamaan GEF

\begin{tabular}{|c|c|c|c|}
\hline \multicolumn{4}{|c|}{ Persamaan Government Effectiveness (GEF) } \\
\hline Peubah & Label & Parameter Estimasi & Prob \\
\hline Intersep & Intersep & -0.06711 & 0.0635 \\
\hline ROL & Rule of Law & 0.294475 & $<.0001$ \\
\hline VOAC & Voice and Accountability & 0.376172 & $<.0001$ \\
\hline
\end{tabular}

Sumber: data diolah (2020) 
Bila dibandingkan, dari kedua variabel, terlihat $V O A C$ memiliki dampak yang lebih besar terhadap $G E F$ daripada ROL. Ini karena reformasi struktural di Indonesia pasca reformasi memang lebih mengedepankan perbaikan aspek kelembagaan untuk kebebasan berkumpul dan menyatakan pendapat. Sementara, hal- hal yang terkait dengan kelembagaan hukum masih belum optimal berjalan. Diindikasikan dari masih banyaknya praktek judicial corruption atau korupsi pengadilan yang dilakukan oleh penegak hukum. Hal ini yang kemudian membuat, secara relatif, dampak $R O L$ lebih rendah dibandingkan $V O A C$.

Tabel 3. Hasil Estimasi Persamaan REGQUA

\begin{tabular}{lccc}
\hline \multicolumn{4}{l}{ Persamaan Regulatory Quality $($ REGQUA) } \\
\hline Peubah & Label & Parameter Estimasi & Prob \\
\hline Intersep & Intersep & -0.24403 & $<.0001$ \\
GEF & Government Effectiveness & 0.332359 & 0.0101 \\
\hline
\end{tabular}

Sumber: data diolah (2020)

Hasil estimasi persamaan REGQUA menunjukkan bahwa terdapat pengaruh positif GEF terhadap REGQUA. Ini berarti makin efektif kinerja pemerintahan dalam menggunakan kekuasan politik dan birokrasinya, maka akan semakin baik pula kualitas regulasi yang dihasilkan. Kualitas regulasi yang baik, secara teoretik, sangat

diperlukan sebagai acuan dasar bersama. Sementara itu, dalam konteks operasional, salah satu alasan pentingnya keberadaan regulasi adalah agar memudahkan proses koordinasi yang pada gilirannya nanti akan memudahkan pelaksanaan kerja berkaitan dengan urusan pemerintahan.

Tabel 4. Hasil Estimasi Persamaan Konsumsi $(C)$

\begin{tabular}{llrl}
\hline \multicolumn{4}{c}{ Persamaan Konsumsi $(\boldsymbol{C})$} \\
\hline Peubah & \multicolumn{1}{c}{ Label } & Parameter & Estimasi \\
\hline Intersep & Intersep & 50815934 & Prob \\
$Y d$ & Pendapatan Disposabel & 0.573564 & 0.0001 \\
$D r$ & Deposit Rate & -780868 & 0.0612 \\
\hline
\end{tabular}

Sumber: data diolah (2020)

Terkait dengan persamaan konsumsi, hasil estimasi memperlihatkan bahwa pendapatan disposabel $(Y d)$ berpengaruh positif terhadap konsumsi. Secara teoretis, bersesuaian dengan teori dasar Keynes. Sementara itu, tingkat suku bunga tabungan memiliki pengaruh yang negatif terhadap konsumsi. Ini terjadi karena peningkatan $\mathrm{Dr}$ mengidikasikan membesarnya opportunity cost dalam membelanjakan uang. Sehingga, kondisi ini orang akan cenderung menahan konsumsinya.

Hasil estimasi juga menunjukkan autonomous consumption yang memiliki nilai positif dan signifikan sesuai dengan teori. Marginal Propensity to Consume (MPC) sebesar 0.57 untuk skala nasional menunjukkan perubahan konsumsi sebesar

0.57 unit untuk setiap 1 unit perubahan disposable income. Dibandingkan periode sebelum krisis, 1986-1996, besaran MPC Indonesia ini menurun sedikit dari angka 0.63. Secara relatif, nilai MPC di Indonesia relatif lebih rendah dibandingkan dengan Korea dan Jepang masing-masing 0.634 dan 0.620. Nilai MPC Indonesia juga lebih rendah dibandingkan Cina (0.540), Philipina (0.835) dan Hong Kong (0.846). Akan tetapi, masih lebih tinggi daripada Singapura (0.478) (Anugrah, 2010).

Terhadap variabel tingkat suku bunga, hasil estimasi menunjukkan respon konsumsi yang cukup besar terhadap perubahan tingkat suku bunga deposito $(D r)$. Dimana diketahui jika terjadi kenaikan tingkat suku bunga $1 \%$, secara agregat, ini akan mengurangi konsumsi 
sekitar Rp781 miliar. Secara teoritis, peningkatan suku bunga deposito $(D r)$ akan menaikkan biaya penggunaan uang periode sekarang sehingga mendorong konsumen untuk mengurangi konsumsi dan mengalihkannya ke periode mendatang.

Tabel 5. Hasil Estimasi Persamaan Investasi (I)

\begin{tabular}{|c|c|c|c|c|}
\hline \multicolumn{5}{|c|}{ Persamaan Investasi $(I)$} \\
\hline Peubah & Label & Parameter & Estimasi & Prob \\
\hline Intersep & Intersep & & 15982036 & 0.1380 \\
\hline$L r$ & Lending Rate & & -321671 & $<.0001$ \\
\hline Regqua & Regulatory Quality & & 53584066 & 0.0035 \\
\hline$Y d$ & Pendapatan Disposabel & & 0.362818 & $<.0001$ \\
\hline Er & Nilai Tukar & & -5990.21 & 0.0003 \\
\hline
\end{tabular}

Sumber: data diolah (2020)

Hasil estimasi persamaan investasi memperlihatkan terdapat pengaruh positif dan signifikan regulatory quality (REGQUA), sebagai salah satu proxy institusi dalam studi ini, terhadap investasi. Kenaikan kualitas regulasi, yang diindikasikan dengan meningkatnya nilai indeks REGQUA sebesar 1 poin, akan menumbuhkan investasi sekitar $\mathrm{Rp} 53.5$ triliun. Ini menunjukkan pentingnya peran insititusi sebagai enabling factor yang dapat mempercepat perbaikan kinerja ekonomi. Oleh karena itu, berbagai aturan yang menghambat dan berbelit, harus dihilangkan. Berbagai upaya struktural yang telah dilakukan tampak belum memberi hasil optimal. Laporan ease of doing business 2019 menempatkan peringkat kemudahan memulai usaha di Indonesia pada posisi 134 dari 222 negara di dunia. Kualitas regulasi yang membuat potensi investasi di Indonesia masih belum dapat dimaksimalkan sepenuhnya. Selain itu, diketahui bahwa adanya dampak negatif dari suku bunga pinjaman riil terhadap investasi. Hal ini bersesuaian dengan teori yang menyebutkan bahwa makin tinggi biaya modal yang dicerminkan dari meningkatnya tingkat suku bunga pinjaman, pelaku usaha akan cenderung mengurangi kegiatan investasi.

Hasil estimasi juga menunjukkan pendapatan disposabel $(Y d)$ dan nilai tukar memiliki pengaruh yang signifikan terhadap investasi, meski dengan arah hubungan yang berbeda. Semakin tinggi pendapatan disposabel, maka investasi juga cenderung meningkat. Tentu hal ini terkait dengan kemampuan daya beli yang menguat seiring dengan adanya pertambahan pendapatan disposabel. Situasi pasar (market) yang lebih menarik sebagai akibat naiknya pendapatan disposabel ini yang kemudian mendorong investasi bertumbuh lebih tinggi. Sementara itu, didapati bahwa depresiasi nilai tukar berpengaruh negatif dan signifikan terhadap investasi. Ini menandakan bahwa makin tinggi tingkat depresiasi nilai tukar Rupiah terhadap Dollar, maka tingkat investasi, secara agregat, akan cenderung menurun. Kondisi ini terjadi karena depresiasi nilai tukar mengakibatkan turunnya nilai riil dari return yang diperoleh dari kegiatan investasi. Hal ini kemudian mengurangi intensi agen ekonomi, khususnya pihak asing, untuk melakukan investasi.

Tabel 6. Hasil Estimasi Persamaan Ekspor $(X)$

\begin{tabular}{|c|c|c|c|}
\hline \multicolumn{4}{|c|}{ Persamaan Ekspor $(X)$} \\
\hline Peubah & Label & Parameter Estimasi & Prob \\
\hline Intersep & Intersep & $-1.028 \mathrm{E} 9$ & $<.0001$ \\
\hline $\mathrm{Er}$ & Nilai Tukar & 16971.61 & $<.0001$ \\
\hline$Y c h$ & Output China & 13393.02 & 0.0001 \\
\hline
\end{tabular}




\begin{tabular}{llll}
\hline Yus & Output Amerika Serikat & 9287.491 & 0.0033 \\
Nonfuel & Harga Komoditas non-fuel & $1.8786 \mathrm{E} 8$ & $<.0001$ \\
I & Investasi & 0.112136 & 0.0327 \\
\hline
\end{tabular}

Sumber: data diolah (2020)

Terkait dengan ekspor, hasil estimasi memperlihatkan adanya pengaruh positif dan signifikan dari variabel nilai tukar, output China dan AS, harga komoditas non-fuel dan juga lag investasi terhadap ekspor. Output China dan Amerika Serikat, dua negara dengan ekonomi terbesar, adalah proxy dari perekonomian global. Kenaikan output kedua negara, yang menandakan adanya peningkatan aktivitas ekonomi global, baik secara langsung maupun tidak langsung, akan meningkatkan ekspor Indonesia. Studi ini menemukan bahwa kenaikan ekspor Indonesia lebih responsif terhadap pertambahan output China daripada Amerika Serikat. Hal ini terjadi karena memang secara bilateral hubungan dagang Indonesia dengan China relatif lebih besar daripada AS. China merupakan mitra dagang terpenting bagi Indonesia. Karena itu, wajar bila ekspor Indonesia lebih responsif terhadap dinamika output China daripada AS.

Sementara itu, karena ekspor Indonesia masih didominasi oleh komoditas non-fuel, maka kenaikan harga komoditas global non-fuel akan meningkatkan nilai ekspor Indonesia. Dampak investasi yang positif menandakan bahwa makin besar investasi akan mampu mendorong kenaikan ekspor lebih besar lagi. Ini terjadi karena investasi yang dilakukan dapat meningkatkan kapasitas produksi, yang sebagiannya dialokasikan untuk memenuhi permintaan ekspor di pasar dunia. Pemerintah bahkan memberikan banyak insentif bagi investasi yang memang berorientasi ekspor, seperti pemberian tax holiday, subsidi ekspor, dan sebagainya.

Tabel 7. Hasil Estimasi Persamaan Impor $(M)$

\begin{tabular}{|c|c|c|c|}
\hline \multicolumn{4}{|c|}{ Persamaan Impor $(M)$} \\
\hline Peubah & Label & Parameter Estimasi & Prob \\
\hline Intersep & Intersep & $-2.083 \mathrm{E} 9$ & $<.0001$ \\
\hline$Y d$ & Pendapatan Disposabel & 0.159103 & $<.0001$ \\
\hline Infus & Inflasi AS & $-4.9766 \mathrm{E} 8$ & 0.0001 \\
\hline Lager & Lag Nilai Tukar & -6230.60 & 0.0191 \\
\hline
\end{tabular}

Sumber: data diolah (2020)

Hasil estimasi pada persamaan impor mendapati bahwa variabel pendapatan disposabel (Yd), Infus dan lag nilai tukar mempengaruhi impor secara signifikan. Dampak positif pendapatan disposabel menandakan bahwa makin tinggi tingkat pendapatan seseorang, maka kecederungannya besaran impor juga akan bertambah besar. Meningkatnya pendapatan membuat kapasitas seseorang dalam melakukan pembelian juga meningkat, yang kemudian mendorong kenaikan permintaan, tidak hanya dalam kuantitas (jumlah) tetapi juga kualitas (variasi). Jika kapasitas produksi tidak mampu memenuhi tambahan permintaan ini, maka pemenuhan kebutuhan akan dilakukan lewat impor. Ini yang membuat impor kecenderungannya akan bertambah seiring dengan adanya peningkatan pendapatan disposabel.

Sementara itu, pengaruh nilai tukar terhadap impor negatif dan signifikan dengan koefesien 6230, yang berarti bahwa setiap nilai tukar terdepresiasi $\mathrm{Rp} 1$ akan menurunkan impor sebesar Rp 6.23 miliar. Dengan kata lain, depresiasi nilai tukar Rupiah terhadap US Dollar akan diikuti dengan penurunan impor. Ini terjadi karena depresiasi nilai tukar mengakibatkan harga 
barang impor secara relatif menjadi lebih mahal. Kenaikan harga relatif ini yang kemudian mengakibatkan permintaan impor menurun dari sebelumnya.

Sejalan dengan kondisi di atas, dampak Infus terhadap impor juga negatif dan signifikan. Infus merupakan proxy dari harga barang yang diperdagangkan di pasar internasional. Karena itu, kenaikan Infus menandakan adanya kenaikan harga-harga barang. Dalam hal ini, jika terjadi kenaikan harga barang, maka impor akan turun dibanding kondisi sebelumnya.

Tabel 8. Hasil Estimasi Persamaan Pekerja

\begin{tabular}{llrl}
\hline \multicolumn{4}{l}{ Persamaan Kesempatan Pekerja (Pekerja) } \\
\hline Peubah & Label & Parameter Estimasi & Prob \\
\hline Intersep & Intersep & 87898128 & $<.0001$ \\
$I$ & Investasi & 0.034490 & $<.0001$ \\
\hline
\end{tabular}

Sumber: data diolah (2020)

Hasil estimasi mendapati bahwa investasi memiliki pengaruh yang positif dan signifikan terhadap kesempatan kerja di Indonesia. Hal ini berarti bahwa makin besar investasi, maka serapan tenaga kerja juga semakin tinggi. Investasi yang meningkat menandakan adanya peningkatan aktivitas ekonomi, serta

mengindikasikan kebutuhan penggunaan input yang bertambah, termasuk tenaga kerja. Karena itu, peningkatan investasi akan menciptakan kesempatan kerja yang lebih besar. Hasil estimasi ini memperkuat argumentasi pentingnya peran investasi dalam mendorong kenaikan kesempatan kerja.

Tabel 9. Hasil Estimasi Persamaan Kemiskinan Perkotaan

\begin{tabular}{|c|c|c|c|}
\hline \multicolumn{4}{|c|}{ Persamaan Kemiskinan Kota (Miskot) } \\
\hline Peubah & Label & Parameter Estimasi & Prob \\
\hline Intersep & Intersep & 54.08325 & $<.0001$ \\
\hline Pekerja & Pekerja & $-3.2 \mathrm{E}-7$ & $<.0001$ \\
\hline $\operatorname{Inf}$ & Inflasi & 0.138126 & $<.0001$ \\
\hline
\end{tabular}

Sumber: data diolah (2020)

Hasil estimasi persamaan kemiskinan kota menunjukkan bahwa peningkatan kesempatan kerja dapat mengurangi tingkat kemiskinan di perkotaan. Dalam hal ini, makin besar lapangan kerja yang dapat diciptakan, maka makin besar pula jumlah orang miskin di perkotaan yang dapat dikurangi. Tentu, ini sangat terkait dengan adanya besaran pendapatan yang diperoleh seseorang ketika ia memiliki pekerjaan. Kemampuan daya beli yang meningkat, seiring dengan tersedianya lapangan kerja dan pendapatan, akan berimplikasi terhadap penurunan tingkat kemiskinan.
Di sisi lain, studi ini menemukan bahwa inflasi yang tinggi akan cenderung mengakibatkan meningkatnya kemiskinan di perkotaan. Ini terjadi karena inflasi yang tinggi menandakan adanya penurunan daya beli pada masyarakat. Implikasinya, jumlah orang miskin akan bertambah. Terkait dengan hal tersebut, penting untuk kemudian mengelola tingkat inflasi pada level yang moderat. Sebab, kemiskinan di Indonesia, termasuk yang ada diperkotaan, relatif responsif terhadap pergerakan harga barang, khususnya bahan kebutuhan pokok. 
Tabel 10. Hasil Estimasi Persamaan Kemiskinan Pedesaan

\begin{tabular}{llrc}
\hline \multicolumn{4}{l}{ Persamaan Kemiskinan Desa (Misdes) } \\
\hline Peubah & Label & Parameter Estimasi & \multicolumn{1}{c}{ Prob } \\
\hline Intersep & Intersep & 15.98446 & $<.0001$ \\
Pekerja & Pekerja & $-5 \mathrm{E}-8$ & 0.0033 \\
Inf & Inflasi & 0.125466 & $<.0001$ \\
\hline
\end{tabular}

Sumber: data diolah (2020)

Sama seperti sebelumnya, hasil estimasi menunjukkan bahwa peningkatan kesempatan kerja dapat mengurangi tingkat kemiskinan di perdesaan. Akan tetapi, jika diamati, dampak pengurangan kemiskinan di desa relatif lebih kecil daripada di kota. Salah satunya adalah karena kesempatan kerja yang terbuka di kota relatif lebih besar dan variatif dibandingkan di desa. Apalagi, investasi yang diarahkan ke daerah kota secara umum juga lebih besar. Maka dari itu, wajar bila kemudian, perubahan tingkat kemiskinan desa lebih tidak responsif terhadap tambahan kesempatan kerja dibandingkan dengan keadaan kemiskinan di kota.

Sejalan dengan itu, studi ini juga menemukan bahwa dampak inflasi terhadap kemiskinan desa lebih rendah dibandingkan dengan kemiskinan kota. Secara umum, tren kenaikan harga di desa

relatif lebih rendah jika dibandingkan dengan perkotaan. Sebab desa, misalnya dalam konteks pangan -yang merupakan kontributor inflasi terbesar-, lebih dekat dengan lokasi produksi. Sehingga, cenderung kenaikan harga di desa relatif lebih rendah. Ini yang kemudian menyebabkan dampak inflasi di desa terhadap kemiskinan secara agregat lebih rendah dibandingkan dengan di perkotaan.

Untuk mengetahui apakah model cukup valid untuk membuat suatu simulasi alternatif kebijakan, maka perlu dilakukan suatu validasi model dengan tujuan untuk menganalisis sejauh mana model tersebut dapat mewakili dunia nyata (Pindyck and Rubinfield 1998). Adapun kriteria statistik untuk memvalidasi nilai pendugaan model ekonometrika yang digunakan dalam studi ini adalah Theil's Inequality Coefficient $(U)$, yang hasilnya adalah sebagai berikut

Tabel 11. Hasil Validasi Model Penelitian

\begin{tabular}{lc}
\hline Variabel & Coefficient $\mathbf{U}$ \\
\hline GEF & 0.0613 \\
Regqua & 0.1267 \\
C & 0.0363 \\
I & 0.0376 \\
X & 0.0193 \\
M & 0.0301 \\
Pekerja & 0.0089 \\
Kemis & 0.0222 \\
Miskot & 0.0227 \\
Misdes & 0.0254 \\
Y & 0.0304 \\
Yd & 0.0313 \\
\hline Sumber: data diolah $(2020)$
\end{tabular}

Nilai koefisien Theil (U) berkisar antara 1 dan 0 . Jika nilai $U$ mendekati nol maka estimasi model atau variabel tersebut semakin valid. Dalam hal ini, jika $U=0$ maka pendugaan model sempurna, jika U $=1$ maka pendugaan model naif. Nilai threshold $U$ yang digunakan dalam penelitian ini adalah 0.3 untuk menilai 
apakah hasil validasi variabel dapat dikatakan baik atau tidak. Berdasarkan hasil uji validasi model didapati bahwa seluruh variabel penelitian memiliki nilai koefesien $U$ yang lebih kecil dari 0.3, yang menandakan bahwa seluruh persamaan yang terdapat di dalam model penelitian telah memenuhi kualifikasi yang baik untuk melakukan simulasi. Ada tiga skenario simulasi kelembagaan yang diterapkan, yakni pertama, kenaikan indeks rule of law sebesar 100 basis poin. Kedua, kenaikan indeks voice and accountability sebesar 100 basis poin. Ketiga, kombinasi kenaikan indeks rule of law dan voice and accountability masing-masing sebesar 100 basis poin.

\begin{abstract}
Hasil simulasi pertama menunjukkan bahwa, jika terjadi peningkatan indeks rule of law di Indonesia sebesar 100 basis poin akibat dilakukannya upaya reformasi kelembagaan hukum yang memadai, dapat meningkatkan indeks efektivitas pemerintah $(G E F)$ sebesar 56.47 persen, yang ini akan memperbaiki kualitas regulasi yang dihasilkan -sebagaimana diproxykan oleh nilai indeks Regqua yang meningkat 15.15 persen. Perbaikan kualitas regulasi dalam perkembangannya dapat menumbuhkan investasi sebesar 4.36 persen, ekspor 0.80 persen, dan kesempatan kerja 1.11 persen.
\end{abstract}

Tabel 12. Hasil Simulasi Model Penelitian (Rule of Law)

\begin{tabular}{|c|c|c|c|}
\hline \multirow{3}{*}{ VARIABEL } & Simulasi I & Simulasi II & \multirow{2}{*}{$\begin{array}{c}\text { Simulasi III } \\
\text { ROL dan VOAC NAIK } \\
1 \text { POIN }\end{array}$} \\
\hline & ROL NAIK 1 POIN & VOAC NAIK 1 POIN & \\
\hline & $\Delta \%$ & $\Delta \%$ & $\Delta \%$ \\
\hline GEF & 56.47 & 83.65 & 190.49 \\
\hline REGQUA & 15.15 & 25.15 & 66.34 \\
\hline $\mathrm{C}$ & 2.79 & 3.54 & 6.19 \\
\hline I & 4.36 & 6.28 & 12.07 \\
\hline$X$ & 0.80 & 0.71 & 1.21 \\
\hline M & 0.71 & 1.12 & 3.11 \\
\hline pekerja & 1.11 & 1.18 & 2.74 \\
\hline kemis & -2.18 & -2.45 & -3.42 \\
\hline MISKOT & -2.00 & -2.43 & -2.29 \\
\hline MISDES & -2.51 & -2.48 & -5.58 \\
\hline Y & 3.01 & 3.90 & 6.86 \\
\hline Yd & 3.09 & 4.02 & 7.06 \\
\hline
\end{tabular}

Sumber: data diolah (2020)

Kinerja fundamental ekonomi yang membaik ini, secara agregat, akan berdampak terhadap peningkatan pertumbuhan ekonomi sekitar 3.01 persen dan pendapatan disposabel masyarakat 3.09 persen. Dampak sosialnya, tingkat kemiskinan baik yang ada di kota maupun di pedesaan dapat diturunkan masingmasingnya 2 persen dan 2.51 persen.

Hasil simulasi kedua menujukkan bahwa jika terjadi peningkatan indeks voice and accountability di Indonesia sebesar 100 basis poin akibat adanya upaya penghargaan terhadap hak sipil untuk menyuarakan aspirasi dan melakukan kontrol terhadap kekuasaan publik yang memadai maka akan meningkatkan indeks efektivitas pemerintah $(G E F)$ sebesar 83.65 persen, yang ini pada gilirannya akan meningkatkan kualitas regulasi yang dihasilkan oleh pemerintah sebesar 25.15 persen. Hal ini dalam perkembangannya menumbuhkan investasi sebesar 6.28 persen, ekspor 0.71 persen, dan kesempatan kerja 1.18 persen.

Secara agregat, hal ini mendorong peningkatan pertumbuhan ekonomi sekitar 3.90 persen dan pendapatan disposabel masyarakat 4.02 persen. Dampak sosialnya, tingkat kemiskinan baik yang ada di kota maupun di pedesaan pun dapat diturunkan, masing- 
masingnya 2 persen dan 2.51 persen. Secara keseluruhan, tingkat kemiskinan turun 2.45 persen.

Hasil simulasi ketiga memperlihatkan jika terjadi peningkatan indeks rule of law dan voice and accountability di Indonesia sebesar 100 basis poin maka akan meningkatkan indeks efektivitas pemerintah $(G E F)$ hingga 190.49 persen, yang ini pada gilirannya akan meningkatkan kualitas regulasi yang dihasilkan oleh pemerintah sebesar 66.34 persen. Peningkatan kualitas kelembagaan ini dalam perkembangannya mampu menumbuhkan investasi hingga mencapai 12.07 persen, ekspor 1.21 persen, dan kesempatan kerja 2.74 persen. Secara agregat hal ini mendorong peningkatan pertumbuhan ekonomi sekitar 6.86 persen dan pendapatan disposabel masyarakat 7.06 persen. Dampak sosialnya, tingkat kemiskinan baik yang ada di kota maupun di pedesaan pun dapat diturunkan, masingmasingnya 2.29 persen dan 5.58 persen. Secara keseluruhan, tingkat kemiskinan di Indonesia, akibat adanya perbaikan kelembagaan, secara subtansial menurun hingga 3.42 persen.

\section{KESIMPULAN DAN IMPLIKASI}

Studi ini bertujuan untuk mengidentifikasi dampak kelembagaan terhadap dinamika perekonomian secara keseluruhan. Berbeda dengan studi-studi sebelumnya yang hanya melihat peran kelembagaan terhadap aspek tertentu, seperti pertumbuhan ekonomi dan kemiskinan, studi ini juga memasukkan berbagai variabel ekonomi lain, seperti penyerapan tenaga kerja, kinerja perdagangan, investasi, inflasi, dan juga pendapatan, yang belum dipertimbangkan di dalam penelitian sebelumnya. Karena melibatkan varibel pengamatan yang lebih besar, maka studi ini memiliki kelebihan, utamanya dalam hal menjelaskan mekanisme transmisi dari peran institusi terhadap perekonomian secara keseluruhan.

Hasil estimasi model menunjukkan pentingnya peran kelembagaan, yang diproxy-kan oleh variabel $R O L, V O A C, G E F$ dan REGQUA, terhadap perekonomian melalui jalur transmisi investasi. Model yang dibangun terbukti mempunyai validasi yang baik, seperti yang diindikasikan oleh nilai koefesien $U$ yang lebih rendah dari 0.3 , sehingga melalui model yang dibangun dapat dilakukan serangkaian simulasi kebijakan. Berdasarkan hasil simulasi didapati pentingnya peran kelembagaan dalam memperbaiki kondisi fundamental ekonomi Indonesia. Ini karena kelembagaan yang baik akan menciptakan struktur insentif yang lebih baik dalam mendukung perbaikan perekonomian.

\section{UCAPAN TERIMA KASIH}

Ucapan terima kasih kepada Pimpinan Fakultas Ekonomi dan Bisnis, Universitas Pancasila.

\section{DAFTAR PUSTAKA}

Acemoglu, D., S. Johnson, and J. Robinson. 2001. "The Colonial Origins of Comparative Development: An Empirical Investigation." American Economic Review, 91:5, pp. 1369-401.

Arora, Vivek., Vamvakidis, Athanasios. (2004). How Much Do Trading Partners Matter for Economic Growth? IMF Working Paper 04/26.

Bayoumi, Tamim., Swiston, Andrew. (2007). Foreign Entanglements: Estimating the Source and Size of Spillovers Across Industrial Countries. IMF Working Paper 07/182.

Billon, Philippe Le,. Good, Elizabeth. (2015). Responding to the commodity bust: Downturns, policies and 
poverty in extractive sector dependent countries. Elsevier.

Buckle, R.A., Kim, K., Kirkham, H.,McLellan, N., Sharma, J. (2007).

A structural VAR Business Cycle Model for a Small Volatile Open Economy. Journal of Economic Model. 24, 990-1017.

Dizioli, Allan., Guajardo, Jaime., Klyuev, Vladimir., Mano, Rui., \& Raissi, Mehdi. (2016). Spillovers from China's Growth Slowdown and Rebalancing to the ASEAN-5 Economies. IMF Working Paper $16 / 170$.

Djaja, Komara. (2009). Impact of the Global Financial and Economic Crisis on Indonesia : A Rapid Assessment. Coordinating Ministry for Economic Affairs Indonesia.

Dungey, M., Fry-McKibbin, R., Linehan, V. (2014). Chinese Resource Demand and the Natural Resource Supplier. Journal of Applied Economy. 46, 167-178.

Dungey, M., Osborn. (2009). Modelling International Linkages for Large Open Economies: US and Euro Area. JEL classification: F41, C32.

Ebert, Laura., Menza, Tania La. (2015). Chile, copper and resource revenue: A holistic approach to assessing commodity dependence. Elsevier, Jurnal of Resources Policy 43 page 101-111.

Ekananda, Mahyus. (2013). Analisis Data Time Series. Mitra Wacana Media.

Enders, W. (2004). Applied Econometric Time Series. Wiley.

Friedman, M. (1957). A Theory of the Consumption Function. Princeton University Press.

Gruss, Bertrand. (2014). After the BoomCommodity Prices and Economic Growth in Latin America and the Caribbean. IMF Working Paper 14/154.
Gujarati, Damodar N. (2004). Basic Econometric. McGrow-Hill.

Gurría, Angel. (2011). China's Emergence as a Market Economy: Achievements and Challenges. OECD.

Hall, R. E. and C. I. Jones. 1999. "Why Do Some Countries Produce so Much More Output Per Worker Than Others?" Quarterly Journal of Economics, 114:1, pp. 83-116.

Hanson, Gordon H., Robertson, Raymond. (2008). China and the Manufacturing Exports of Other Developing Countries. UCSD and NBER.

Hapsari, A. P., Iskandar, D. D. (2018). Analisis Faktor-Faktor yang Mempengaruhi Pertumbuhan Ekonomi Provinsi Jawa Tengah Periode 2010 - 2014. Jurnal Ilmu Ekonomi dan Pembangunan, Vol 18.

Hoshray, Atanu., Pundit, Madhavi. (2016). The Impact of a People's Republic of China Slowdown on Commodity Prices and Detecting the Asymmetric Responses of Economic Activity in Asian Countries to Commodity Price Shocks. ADB Economics Working Paper Series No. 493.

Hossain, Akhtar. (2006). Sources of Economic Growth in Indonesia, 1966-2003. Applied Econometrics and International Development. AEID. Vol. 6-2.

Junaidi., Patra, I. K. (2017). Korupsi, Pertumbuhan Ekonomi dan Kemiskinan di Indonesia. Riset Akuntansi dan Keuangan Indonesia, Vol. 3(1), pp. $71-79$.

Kose, M. Ayhan., Lakatos, Csilla., Ohnsorge, Franziska., \& Stocker, Marc. (2017). The Global Role of the U.S. Economy : Linkages, Policies and Spillovers. World Bank.

Krugman, Obstfeld, Melitz. (2012). International Economics. Theory and Policy. Addison-Wesley Pearson.

Mankiw, G. (2003). Macroeconomics. Worth Publishers. 
Morrison, Wayne M. (2018). China's Economic Rise: History, Trends, Challenges, and Implications for the United States. Congressional Research Service.

Nezky, Mita. (2013). The Impact of US Crisis on Trade and Stock Market in Indonesia. Bulletin of Monetary, Economics and Banking.

Osborn, Denise R., Vehbi, Tugrul. (2015). Growth in China and the US: Effects on a small commodity exporter economy. Journal of Economic Modelling 45 page 268-277.

Prasmuko, A., Anugrah, D. F. (2010). Dampak Krisis Keuangan Global terhadap Perekonomian Daerah. Buletin Ekonomi Moneter dan Perbankan.

Pindyck, R., Rubinfield, D. L. (1998). Econometric Models and Economic Forecasts. New York: McGraw Hill.

Raz, Arisyi F., Indra, Tamarind P. K.., Artikasih, Dea K.., \& Citra, Syalinda. (2012). Global Financial Crises and Economic Growth : Evidence from East Asian Economies. Bulletin of Monetary, Economics and Banking.

Roache, Shaun K. (2012). China's Impact on World Commodity Markets. IMF Working Paper 12/115.

Romer, David. (2012). Advanced Macroeconomics. McGraw-Hill.

Sato, K., Zhang, Z., McAleer, M. (2011). Identifying Shocks in Regionally Integrated East Asian Economies with Structural VAR and Block Exogeneity. Journal of Math. Comput. Simulation No: 81, 13531364.

Stiroh, K. J. (2000). Investment and Productivity Growth: A Survey From the Neoclasiccal and New Growth Perspective. Research Publications Program Industry Canada.

Sugema, Iman. (2012). 2008-2009 ${ }^{\text {th }}$ Global Financial Crisis and Its Implications on Indonesian Economy. JIPI. Vol. 17 (3): 145-152.

Takatoshi, Ito., Sato, Kiyotaka., (2007). Exchange Rate Pass-Through and Domestic Inflation: A Comparison between East Asia and Latin American Countries. The Research Institute of Economy, Trade and Industry.

Tambunan, Tulus T. H. (2010). The Indonesian Experience with Two Big Economic Crises. Journal of Modern Economy, page 156-167.

Wanjuu, L., Roux, P. (2017). Economic Institutions and Economic Growth: Empirical Evidence from the Economic Community West Africa States. South African Journal of Economic and Management Sciences.

Yuliadi, I. (2008). Analisis Impor Indonesia: Pendekatan Persamaan Simultan. Jurnal Ekonomi dan Studi Pembangunan, Vol. 9, No. 1.

Zhai, Fan., \& Morgan, Peter. (2016). Impact of the People's Republic of China's Growth Slowdown on Emerging Asia : A General Equilibrium Analysis. Asian Development Bank Institute, Working Paper Series No.560.

Zhu, Xiaodong. (2012). Understanding China's Growth: Past, Present, and Future. Journal of Economic Perspectives, Volume 26, Number 4, Pages 103-124. 